Article

\title{
Theoretical study of the geminal methylation of methylbenzene by halomethane over HSAPO-34 molecular sieve
}

\author{
Lingtao Kong, Benxian Shen * \\ State Key Laboratory of Chemical Engineering, East China University of Science \& Technology, 200237, Shanghai, China
}

\section{A R T I C L E I N F O}

Article history:

Received 22 January 2015

Accepted 20 March 2015

Published 20 July 2015

\section{Keywords:}

Geminal methylation

Chloromethane

Bromomethane

SAPO-34 zeolite

Periodic density functional theory

\begin{abstract}
A B S T R A C T
Periodic density functional theory calculations have been conducted using the DMol3 package to investigate the geminal methylation of a series of methylbenzenes as hydrocarbon pool species trapped within the framework of a catalyst for the conversion of methyl halides to light olefins. The adsorption energies of $\mathrm{CH}_{3} \mathrm{Cl}(-18 \mathrm{~kJ} / \mathrm{mol})$ and $\mathrm{CH}_{3} \mathrm{Br}(-22 \mathrm{~kJ} / \mathrm{mol})$ into a SAPO-34 catalyst were calculated, and the results revealed that these methylating agents were not being accurately distinguished because of similarities in the electronegativities of their halogen atoms. The reaction energies and energy barriers were also obtained for the geminal methylation reactions of a series of methylbenzenes using $\mathrm{CH}_{3} \mathrm{Cl}$ and $\mathrm{CH}_{3} \mathrm{Br}$. The results of these calculations suggested that the geminal methylation of hexamethylbenzene (HMB) was exothermic based on the negative reaction energies, whereas the geminal methylation reactions of all of the other methylbenzenes were endothermic. Furthermore, the energy barriers for the geminal methylation of $\mathrm{HMB}$ with $\mathrm{CH}_{3} \mathrm{Cl}$ and $\mathrm{CH}_{3} \mathrm{Br}$ were lower than those of the other methylbenzenes evaluated in the current study, which indicated that HMB was forming strong electrostatic interactions within the structural framework of the molecular sieves, and that the reactivity of the methylbenzene substrate increased as the number of methyl groups increased.
\end{abstract}

(c) 2015, Dalian Institute of Chemical Physics, Chinese Academy of Sciences. Published by Elsevier B.V. All rights reserved.

\section{Introduction}

Direct and non-syngas methods for the conversion of methane to bulk chemicals represent one of the most challenging areas of research in catalysis [1]. However, during the past few decades, a promising alternative has emerged for the conversion of methane to high-value hydrocarbons. According to this process, methane is initially converted to monosubstituted methyl halides, which are subsequently converted to high-value hydrocarbons using zeolite catalysts under relatively mild conditions, and this process has consequently attracted considerable attention from researchers working in academic and industrial fields. Significant research efforts have been directed towards developing a better understanding of the mechanisms underlying the conversion of methyl halides to hydrocarbons, which represents a similar transformation to the methanol to olefins (MT0) process [2-6]. The results of our previous study showed that the selectivity of light olefins, including ethylene, propylene and butene, was almost $90 \%$ and that the initial chloromethane conversion of these substrates was close to $100 \%$ in a chloromethane to light olefins process over a SAPO-34 catalyst [5]. Xu et al. [7] reported that the selectivity of propylene could reach $67 \%$, while that of butene was only $23 \%$ for the conversion of chloromethane to hydrocarbons over HZSM-5 molecular sieve that had been modified with an $\mathrm{NH}_{4} \mathrm{~F}$ solution. Compared with the SAPO-34 catalyst, there are several advantages associated with the use of HZSM-5 molecular sieves as a catalyst in the chloromethane conversion to produce

* Corresponding author. Tel: +86-21-64252916; Fax: +86-21-64252851; E-mail: sbx@ecust.edu.cn 
propylene and higher olefins. Furthermore, the product distribution and reaction mechanism characteristics of these transformations are strongly influenced by the topological features of the catalysts [5]. It is noteworthy that the intermediate species generated during the conversion of methyl halides to hydrocarbons over HSAPO-34/HZSM-5 catalysts are mainly methylbenzenes $[3,5]$.

However, the mechanisms associated with the conversion of methyl halides to olefins over microporous zeolite catalysts currently remain unclear because of the occurrence of uncontrollable and complicated secondary reactions [8]. It is widely acknowledged that the transformation of methyl halides follows the hydrocarbon pool (HP) mechanism, which was initially proposed for the MTO conversions described by Dahl and Kolboe [9]. According to the mechanism for the MTO reaction, the bulky HP species are retained within the structural framework of the zeolite, where they interact with methanol to give hydrocarbon compounds via a closed and indirect reaction route. Furthermore, the inorganic zeolite material and the organic HP species can interact with each other to form an active catalytic framework. Numerous reports have been published during the last few years pertaining to the role of methylbenzenes and their cationic derivatives as catalytic engines in the conversion of methyl halides to olefins over SAPO-34 and HZSM- 5 catalysts [7,10-12].

Two different mechanisms have been proposed for the formation of alkenes from methylbenzenes, including the sidechain methylation and the paring mechanisms [13]. The sidechain methylation mechanism involves the germinal methylation of methylbenzene and the subsequent formation of an exocyclic double bond, which can be further methylated to form light olefins. Li et al. [14] were the first group to verify the existence of a heptamethylbenzenium cation over SAPO-type molecular sieves, which provided further support to the side-chain methylation mechanism. The paring mechanism also involves the initial geminal methylation of methylbenzene, although the following step involves the contraction of the benzene ring to give an alkyl substituent, which can be cracked to form light olefins. The starting point for both of the mechanisms mentioned above is the geminal methylation step, where a carbon atom of the benzene ring is methylated, resulting in the loss of aromaticity and the formation of a benzenium cation, as shown in Scheme 1 [15]. Furthermore, the product distribution for the conversion of methyl halides to olefins would be heavily influenced by the nature of the HP species. The results of several key studies have implied that mono-, di- and trimethylbenzenes are conducive to the formation of ethene, whereas tetra-, penta- and hexamethylbenzenes favor the formation of propylene $[7,16]$.

Although significant experimental and theoretical contribu-

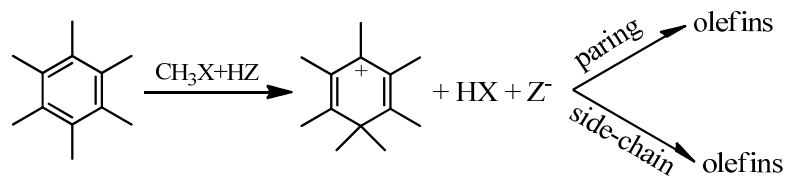

Scheme 1. The methylation reaction of HMB using halomethane as a methylating agent. $X=\mathrm{Cl}$ or $\mathrm{Br}$; $\mathrm{HZ}=\mathrm{HSAPO}-34$. tions have been made by numerous researchers during the last few years to reveal the actual mechanisms involved in the conversion of methyl halides to olefins, the details of the elementary reaction steps still remain unclear $[8,17,18]$. Further research is therefore urgently required for many targets, especially those involved in controlling the product distribution and improving the catalytic performance, to develop a deeper atomic-level understanding of these processes.

Herein, density functional theory (DFT) calculations have been used to investigate the geminal methylation of a series of different methylbenzenes, including $p$-xylene (PX), 1,3,5-trimethylbenzene (TriMB), 1,3,4,5-tetramethylbenzene (TetraMB), pentamethylbenzene (PMB) and hexamethylbenzene (HMB), using chloromethane and bromomethane over microporous SAPO-34 molecular sieves with a CHA cage. The use of iodomethane as a reactant was also investigated but resulted in the formation of $I_{2}$ even when the reaction was conducted in the absence of the catalyst [11]. For this reason, the current study has focused exclusively on the use of chloromethane and bromomethane as methylating agents.

Calculations based on the geminal methylation reaction could be used to distinguish between the different methylbenzene molecules and develop a better understanding of the interactions between the methylbenzene and the catalyst framework. Wang et al. [19] investigated the effects of how different methylbenzenes in the pores of the HSAPO-34 catalyst impact on the conversion of methanol to olefins using the first principle method, and the result demonstrated that methylbenzenes with five or six methyl groups were less active than those with fewer methyl groups. In this study, the geminal methylation reactions of methylbenzenes with halomethanes have been calculated using periodic DFT by taking in account the topology and intrapore electrical environment of the catalyst.

\section{Computational methods and modeling}

The DFT calculations were performed using the DMol3 software package with the Materials Studio program system [18]. The calculations were performed using the GGA/RPBE density functionals and the double numerical polarization basis set. The core electrons of all of the atoms were represented by DFT semicore pseudopotentials. The real space cutoff distance was set at $0.50 \mathrm{~nm}$ in all calculations. The reciprocal-space integration over the Brillouin zone was approximated by summing over a finite set of k-points with a grid separation of 0.005 $\mathrm{nm}^{-1}$ according to the Monkhorst-Pack scheme. For the adsorption calculations, the convergence criteria in DMol3 were set to $1 \times 10^{-1}$ Hartree for energy, 0.02 Hartree/nm for maximum force and $0.0005 \mathrm{~nm}$ for maximum displacement. Furthermore, the self-consistent field (SCF) tolerance was set to $1 \times 10^{-6} \mathrm{Har}-$ tree with multipolar expansion through an octupole moment. For the transition states, the convergence criteria for energy, force and displacement were set to $1 \times 10^{-4}$ Hartree, $4 \times 10^{-2}$ Hartree/nm and $5 \times 10^{-4} \mathrm{~nm}$, respectively. Linear synchronous transition (LST) and quadratic synchronous transition (QST) searches were used to search the transition state. Transition 
state optimization through an eigenvector following a method based on vibrational analysis was conducted to ensure that exactly one imaginary frequency was at hand.

The unit cell chosen for the calculations described below was taken from a CHA structure in the materials studio database, and all of the Si atoms in the CHA framework were alternately replaced with $\mathrm{P}$ and $\mathrm{Al}$ atoms $[18,19]$. One of the $\mathrm{P}$ atoms was subsequently replaced with a $\mathrm{Si}$ atom to generate a Brönsted acidic site in each cage. The structure parameters of the resulting unit cell were $a=b=c=0.9421 \mathrm{~nm}, \alpha=\beta=\gamma=$ $94.2^{\circ}$. The proton was located on an acidic oxygen atom, which was part of one 4-membered ring and two 8-membered rings. The other acidic oxygen was part of a 4-, 6- and 8-membered framework of rings. Lo and Trout [20] reported that the acidities of the four acidic sites in chabazite were approximately the same according to the measured adsorption energies of various bases with DFT methods, which suggested that the acidities of the acidic sites in chabazite were not being significantly influenced by chemical or structural variations in the framework near to the acid sites. As part of our simulation work, all of the atoms in the super cell were allowed to relax and the lattice constants of the super cell were fixed.

The adsorption energy was defined as follows:

$$
E_{\text {ads }}=E_{\mathrm{HSAPO}-34+\mathrm{CH}_{3} \mathrm{X}}-E_{\mathrm{HSAPO}-34}-E_{\mathrm{CH}_{3} \mathrm{X}}
$$

The transition state reaction energy barrier was calculated as follows [21]:

$$
E_{\text {barrier }}=E_{\text {transition state }}-E_{\mathrm{HSAPO}-34+\text { methylbenzene }+\mathrm{CH}_{3} \mathrm{X}}
$$

\section{Results and discussion}

The adsorption geometries of $\mathrm{CH}_{3} \mathrm{Cl}$ and $\mathrm{CH}_{3} \mathrm{Br}$ on protonated SAPO-34 are displayed in Fig. 1. Compared with methanol, there were no hydrogen bonding interactions between the halomethanes and the SAPO-34 catalyst. The replacement of one hydrogen atom in the methane molecule with a halogen atom effectively activated the otherwise inert compound, which adopted a regular tetrahedral structure. The electronegativity of chlorine and bromine are 3.0 and $2.8 \mathrm{eV}$, respectively. Interestingly, the adsorption energy of $\mathrm{CH}_{3} \mathrm{Cl}$ and $\mathrm{CH}_{3} \mathrm{Br}$ was -18 and $-22 \mathrm{~kJ} / \mathrm{mol}$, respectively, showing the opposite trend to the electronegativity. Bleken et al. [21] reported that the adsorption energy of $\mathrm{CH}_{3} \mathrm{Cl}$ into a SAPO-34 catalyst was -15 $\mathrm{kJ} / \mathrm{mol}$ with an identical level of computational accuracy. Any deviation from the adsorption model could therefore disturb the trend between the adsorption energy and the electronegativity.
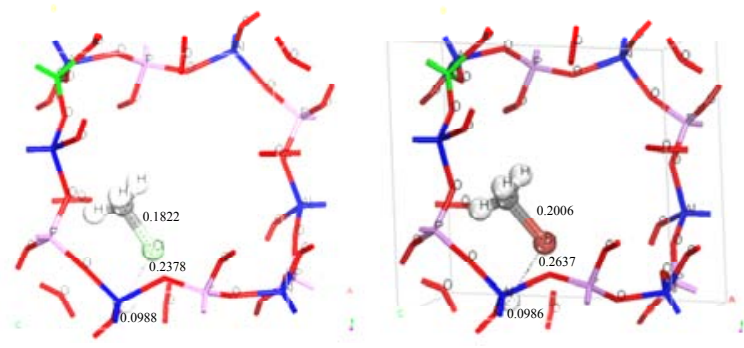

Fig. 1. Adsorption geometries of chloromethane (left) and bromomethane (right) on HSAPO-34.
The adsorption geometric parameters for $\mathrm{CH}_{3} \mathrm{Cl}$ and $\mathrm{CH}_{3} \mathrm{Br}$ onto HSAPO-34 are summarized in Table 1. For the adsorption state of the halomethane molecule, the $\mathrm{OH}$ distance in the HSAPO-34 catalyst was slightly extended from 0.0975 to $0.0988 \mathrm{~nm}\left(0.0986 \mathrm{~nm}\right.$ for $\left.\mathrm{CH}_{3} \mathrm{Br}\right)$ because of the electrostatic force of the halogen. Furthermore, the $\mathrm{C}-\mathrm{Cl} / \mathrm{Br}$ bond distances in the halomethane compounds also increased in length, as listed in Table 1. The $\mathrm{C}-\mathrm{H}$ distances in $\mathrm{CH}_{3} \mathrm{Cl}$ and $\mathrm{CH}_{3} \mathrm{Br}$ became slightly shorter following their adsorption onto HSAPO-34, which suggested that the forces of interaction between the $\mathrm{C}$ and $\mathrm{H}$ atoms in the halomethane could be enhanced.

Five different methylbenzenes were evaluated in this study. Fig. 2 shows a schematic representation of the geminal methylation reactions of $\mathrm{PX}$ with $\mathrm{CH}_{3} \mathrm{Cl}$ and $\mathrm{CH}_{3} \mathrm{Br}$ on the SAPO-34 catalyst. The structural parameters, reaction energies and the energy barriers for the geminal methylation reactions of all five methylbenzenes are displayed in Table 2. Schematic diagrams of the geometric parameters could help us to develop a better understanding of the key structural relationships in the transition states, as shown in Fig. 3.

In the presence of PX trapped into the cage of CHA, the adsorbed halomethane molecule could attack one of the carbons in the benzene ring. At the transition state of the geminal methylation processes, the methyl group would be pointing away from the halogen atom and would gradually move closer to the benzene molecule. The $\mathrm{O}-\mathrm{H}$ distance of the zeolite would be extended from 0.1007 to $0.1126 \mathrm{~nm}$, and the halogen atom would move closer to the proton during the geminal methylation processes. The central methyl group would present a quasi-planar structure with an umbrella-type inversion, and the $\mathrm{Cl} / \mathrm{Br}-\mathrm{C}_{1} \mathrm{C}_{2}$ bond angles would be $175.4^{\circ}$ and $174.7^{\circ}$, respectively, which are close to being straight in both cases. The breaking of the $\mathrm{Cl}(\mathrm{Br})-\mathrm{C}$ bond would occur at $0.2602 \mathrm{~nm}$ $(0.2780 \mathrm{~nm})$, while the formation of the $\mathrm{C}-\mathrm{C}$ bond would occur at $0.2151 \mathrm{~nm}\left(0.2107 \mathrm{~nm}\right.$ for $\left.\mathrm{CH}_{3} \mathrm{Br}\right)$. In conclusion, the geminal methylation reactions of the different methylbenzenes with halomethanes would follow an $\mathrm{S}_{\mathrm{N}} 2$-type mechanism, which is similar to the mechanism reported by Wang et al. [18], where methanol was used as a methylating agent.

The final step of the reaction would lead to the formation of the corresponding benzenium cations and hydrogen halide. The benzenium cations of the different methylbenzenes would completely lose their aromatic properties based on the obvious changes in the $\mathrm{C}-\mathrm{C}$ bond lengths of the benzene rings. For the geminal methylation reaction of $\mathrm{PX}$ with $\mathrm{CH}_{3} \mathrm{Cl}$, the bond distances between the two benzene ring carbon atoms and the carbon atom attacked by $\mathrm{CH}_{3} \mathrm{Cl}$ were 0.1483 and $0.1484 \mathrm{~nm}$, while the distances between the two newly formed $\mathrm{C}=\mathrm{C}$ double

Table 1

Geometric parameters for the adsorption states of $\mathrm{CH}_{3} \mathrm{Cl}$ and $\mathrm{CH}_{3} \mathrm{Br}$ on HSAPO-34.

\begin{tabular}{lcccc}
\hline Sample & $\mathrm{ZeO}-\mathrm{H}(\mathrm{nm})$ & $\mathrm{C}-\mathrm{Cl} / \mathrm{Br}(\mathrm{nm})$ & $\mathrm{C}-\mathrm{H}(\mathrm{nm})$ & $\mathrm{ZeOH}-\mathrm{Cl} / \mathrm{Br}(\mathrm{nm})$ \\
\hline $\mathrm{HSAPO}-34$ & 0.0975 & - & - & - \\
$\mathrm{CH}_{3} \mathrm{Cl}$ & - & 0.1808 & 0.1095 & - \\
$\mathrm{CH}_{3} \mathrm{Br}$ & - & 0.1996 & 0.1093 & - \\
$\mathrm{ZeOH}-\mathrm{CH}_{3} \mathrm{Cl}$ & 0.0988 & 0.1822 & 0.1093 & 0.2378 \\
$\mathrm{ZeOH}-\mathrm{CH}_{3} \mathrm{Br}$ & 0.0986 & 0.2006 & 0.1091 & 0.2637 \\
\hline
\end{tabular}



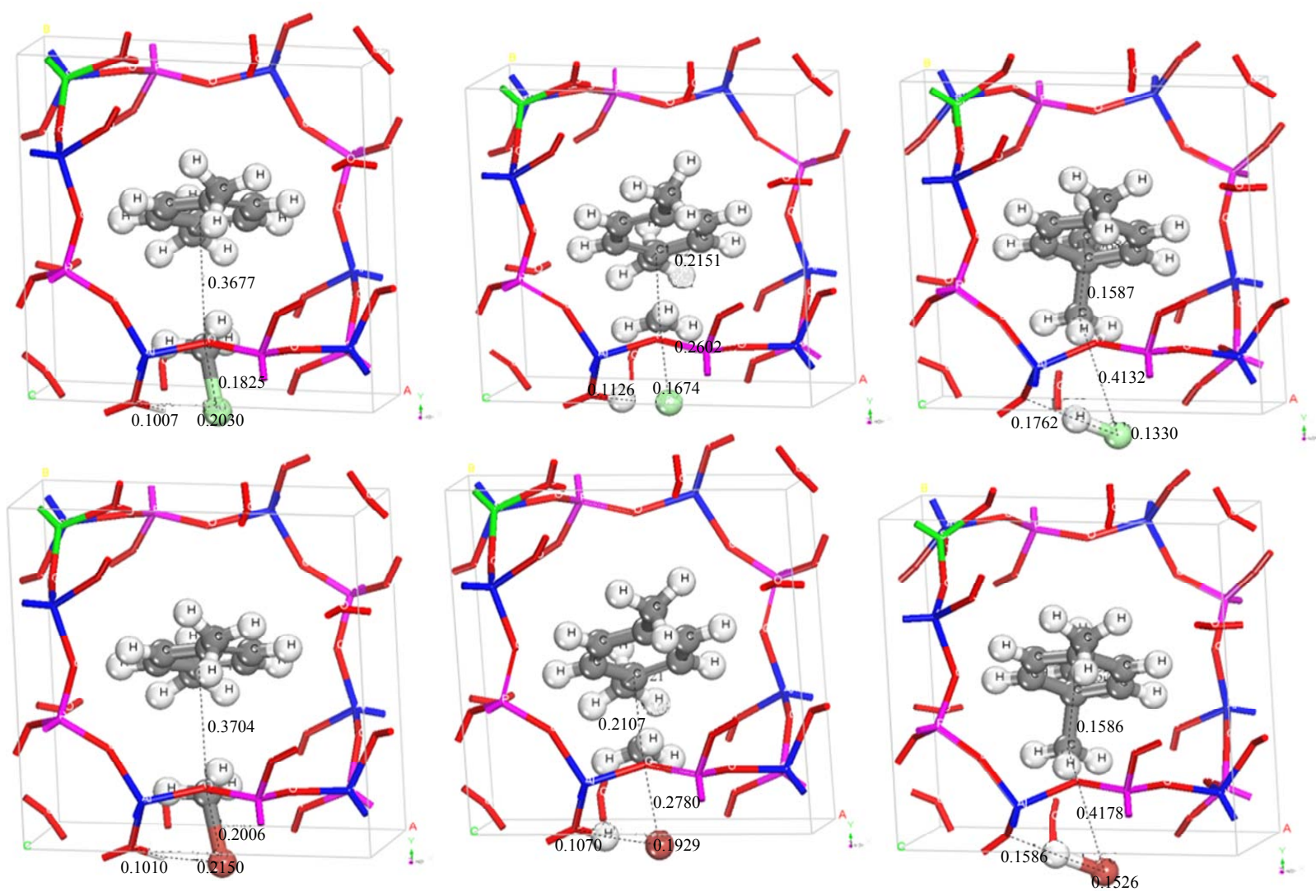

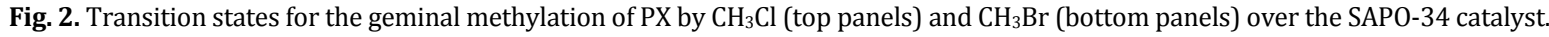

Table 2

Structural parameters and energy barriers of the transition states for the geminal methylation reactions of different methylbenzenes over the SAPO-34 catalyst.

\begin{tabular}{|c|c|c|c|c|c|c|c|c|c|}
\hline \multirow{2}{*}{ Structure } & \multicolumn{5}{|c|}{$\mathrm{CH}_{3} \mathrm{Cl}$} & \multicolumn{4}{|c|}{$\mathrm{CH}_{3} \mathrm{Br}$} \\
\hline & PX & TriMB & TetraMB & PMB & HMB & PX & TriMB & PMB & HMB \\
\hline$\overline{\mathrm{C}_{1} \mathrm{C}_{2}(\mathrm{~nm})}$ & 0.2151 & 0.2155 & 0.2192 & 0.2184 & 0.2219 & 0.2107 & 0.2103 & 0.2159 & 0.3647 \\
\hline $\mathrm{C}_{1}-\mathrm{Cl}(\mathrm{Br})(\mathrm{nm})$ & 0.2602 & 0.2603 & 0.2527 & 0.2559 & 0.2488 & 0.2780 & 0.2775 & 0.2754 & 0.2025 \\
\hline $\mathrm{Cl}(\mathrm{Br})-\mathrm{H}(\mathrm{nm})$ & 0.1674 & 0.1635 & 0.1677 & 0.1705 & 0.1680 & 0.1929 & 0.1901 & 0.1950 & 0.1533 \\
\hline $\mathrm{ZeO}-\mathrm{H}(\mathrm{nm})$ & 0.1126 & 0.1143 & 0.1129 & 0.1118 & 0.1121 & 0.1071 & 0.1076 & 0.1071 & 0.1858 \\
\hline$\angle \mathrm{Cl} / \mathrm{Br}-\mathrm{C}_{1} \mathrm{C}_{2}\left({ }^{\circ}\right)$ & 175.4 & 171.1 & 177.2 & 177.0 & 177.6 & 174.7 & 171.7 & 176.9 & 172.0 \\
\hline$\angle \mathrm{C}_{1} \mathrm{C}_{2} \mathrm{C}_{3}\left(^{\circ}\right)$ & 102.8 & 102.3 & 101.0 & 102.8 & 99.9 & 102.9 & 101.5 & 105.2 & 101.9 \\
\hline$\Delta E_{\mathrm{r}}(\mathrm{kJ} / \mathrm{mol})$ & 57.0 & 64.3 & 9.6 & 28.0 & -65.6 & 71.8 & 75.7 & 41.8 & -50.4 \\
\hline$\Delta E_{\mathrm{b}}(\mathrm{kJ} / \mathrm{mol})$ & 158.0 & 137.3 & 109.7 & 119.4 & 30.7 & 114.9 & 128.3 & 107.6 & 46.0 \\
\hline
\end{tabular}

bonds were 0.1369 and $0.1370 \mathrm{~nm}$. Finally, the remaining C-C bond lengths in the benzenium cations were 0.1427 and 0.1426 $\mathrm{nm}$. Interestingly, the use of $\mathrm{CH}_{3} \mathrm{Br}$ as a methylating agent did not result in the formation of a geminal methylation transition state for the TetraMB using the same computational set.

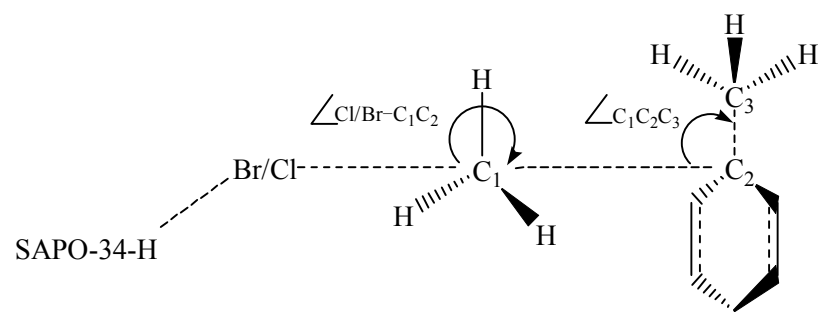

Fig. 3. Schematic diagram of the geometric parameters in the transition state structure.
The reaction energy was positive for the geminal methylation reactions of $\mathrm{PX}$, TriMB, TetraMB and $\mathrm{PMB}$ using $\mathrm{CH}_{3} \mathrm{Cl}$ and $\mathrm{CH}_{3} \mathrm{Br}$ as the methylating agents, as listed in Table 2. These results therefore suggest that the geminal methylation reactions of these compounds are endothermic processes. However, the geminal methylation reactions of $\mathrm{HMB}$ using $\mathrm{CH}_{3} \mathrm{Cl}$ and $\mathrm{CH}_{3} \mathrm{Br}$ as the methylating agents were determined to be exothermic based on their negative reaction energy of -65.6 and $-50.4 \mathrm{~kJ} / \mathrm{mol}$. Lesthaeghe et al. [15] reported that the theoretically calculated reaction energy for the geminal methylation of HMB was also the lowest of all of the methylbenzenes evaluated in the 5T cluster and MFI structure (except durene). Notably, the reaction energy for the geminal methylation of HMB was determined to be $-8.4 \mathrm{~kJ} / \mathrm{mol}$ using the CHA model, and the disparity between this result and our own results most likely 
relates to differences in the computational models.

The energy barriers (from $158-30.7 \mathrm{~kJ} / \mathrm{mol}$ ) for the geminal methylation reactions involving $\mathrm{CH}_{3} \mathrm{Cl}$ gradually decreased as the number of methyl groups on the benzene ring increased (except PMB). The reaction energy and energy barrier for the geminal methylation of $\mathrm{PMB}$ with $\mathrm{CH}_{3} \mathrm{Cl}$ were 28.0 and 119.4 $\mathrm{kJ} / \mathrm{mol}$, respectively. In other words, the variations in the energy barriers for the geminal methylation reactions of the different methylbenzenes were not consistent with the molecular sizes, as listed in Table 2. Lesthaeghe et al. [15] systematically investigated the geminal methylation reactions of a variety of different methylbenzenes, which had been confined into a space-limiting MFI structure, and their findings indicated that the variation in the energy barriers of these reactions was not consistent with the increasing number of methyl groups on the methylbenzenes. The low convergence criteria for all of these calculations could result from the processes involved during the search for the transition state. It is noteworthy that zeolite confinement effects, including electrostatic stabilization, space limitations, shape selectivity, rotational mobility and the breathing of the framework have been reported to have a significant impact on the reactivity of the bulky molecules involved in the MTO process [23]. In a limited space, with an increasing number of methyl groups on the methylbenzene structure, two opposing effects would be encountered by the geminal methylation reaction [15]. For the first of these effects, the increasing number of methyl groups would lead to stronger electrostatic interactions between the zeolite framework and the methylbenzene substrate, which would lead to an improvement in the reactivity of the HP species. For the second effect, the increasing molecular size of the methylbenzenes would lead to a gradual increase in the geometric constraints imposed on the reaction, especially in the process of molecular rotation. These two opposing effects would therefore be the main reasons for the fluctuation and incompatible changes displayed in Table 2.

When $\mathrm{CH}_{3} \mathrm{Br}$ was used as a methylating agent, the energy barriers followed the order TriMB > PX > PMB > HMB, which revealed further fluctuations and incompatible changes in the energy barriers. This trend could also be explained in terms of the reasoning provided above. Furthermore, the differences between $\mathrm{CH}_{3} \mathrm{Cl}$ and $\mathrm{CH}_{3} \mathrm{Br}$ only had a limited effect on the energy barrier, and it is noteworthy that $\mathrm{HMB}$ readily overcame the $30.7 \mathrm{~kJ} / \mathrm{mol}$ (or $46.0 \mathrm{~kJ} / \mathrm{mol}$ ) energy barrier to form the corresponding benzenium cation using both of these methylating reagents. In other words, the geminal methylation reaction of HMB occurred much more readily than those of the only methylbenzenes evaluated in the current study, which has been verified experimentally in several studies $[2,7,24,25]$. The higher reactivity of HMB could be attributed to its ability to form stronger electrostatic interactions within the framework of the molecular sieves based on the increasing number of methyl groups. The electrostatic interaction between methylbenzenes and the framework could therefore have an extremely important impact on geminal methylation reactions conducted in a limited space, which could offset the segmental resistance from the rotation of the bulky intermediate species. Olsbye et al. [2] reported the conversion of methyl halides to hydrocarbons using an isotopic labeling technique, and the result clearly showed that HMB contained a similar or higher ${ }^{13} \mathrm{C}$ fraction than the alkenes 1-5 min after switching, which suggested that HMB was an extremely important reaction intermediate in the formation of alkenes from chloromethane over HSAPO-34 catalyst. The results of this study were in agreement with the previous results for the MTO reaction [26,27].

\section{Conclusions}

The adsorption energy for $\mathrm{CH}_{3} \mathrm{Cl}$ and $\mathrm{CH}_{3} \mathrm{Br}$ onto a SAPO-34 catalyst has been investigated using periodic density functional theory calculations, which could not accurately distinguish between the close electronegativities of the halogen atoms. The geminal methylation reactions of several different methylbenzenes with $\mathrm{CH}_{3} \mathrm{Cl}$ and $\mathrm{CH}_{3} \mathrm{Br}$ were studied, and the results indicated that these reactions followed an $\mathrm{S}_{\mathrm{N}} 2$-type mechanism in a similar manner to MTO reactions, which use methanol as a methylating agent. The geminal methylation reactions of HMB with $\mathrm{CH}_{3} \mathrm{Cl}$ and $\mathrm{CH}_{3} \mathrm{Br}$ were determined to be exothermic based on the reaction energy, whilst the geminal methylation reactions of the other methylbenzenes were endothermic. The energy barriers for the geminal methylation reactions with $\mathrm{HMB}$ with $\mathrm{CH}_{3} \mathrm{Cl}$ and $\mathrm{CH}_{3} \mathrm{Br}$ were the lowest of all of the methylbenzenes tested in the current study, which suggested that the geminal methylation of HMB was a facile process despite the bulky structure.

\section{References}

[1] Alvarez-Galvan M C, Mota N, Ojeda M, Rojas S, Navarro R M, Fierro J L G. Catal Today, 2011, 171: 15

[2] Olsbye U, Saure O V, Muddada N B, Bordiga S, Lamberti C, Nilsen M H, Lillerud K P, Svelle S. Catal Today, 2011, 171: 211

[3] Zhang D Z, Wei Y X, Xu L, Chang F X, Liu Z Y, Meng S H, Su B L, Liu Z M. Microporous Mesoporous Mater, 2008, 116: 684

[4] Kong L T, Jiang Z, Zhao J G, Liu J C, Shen B X. Catal Lett, 2014, 144: 1609

[5] Kong L T, Shen B X, Zhao J G, Liu J C. Ind Eng Chem Res, 2014, 53 : 16324

[6] Zhang A H, Sun S L, Komon Z J A, Osterwalder N, Gadewar S, Stoimenov P, Auerbach D J, Stucky G D, McFarland E W. Phys Chem Chem Phys, 2011, 13: 2550

[7] Xu T, Zhang Q H, Song H, Wang Y. J Catal, 2012, 295: 232

[8] Dai W L, Wang C M, Dyballa M, Wu G J, Guan N J, Li L D, Xie Z K, Hunger M. ACS Catal, 2015, 5: 317

[9] Dahl I M, Kolboe S. J Catal, 1994, 149: 458

[10] Wei Y X, Zhang D Z, Liu Z M, Su B L. J Catal, 2006, 238: 46

[11] Svelle S, Aravinthan S, Björgen M, Lillerud K P, Kolboe S, Dahl I M, Olsbye U.J Catal, 2006, 241: 243

[12] Wei Y X, Zhang D Z, Chang F X, Xia Q H, Su B L, Liu Z M. Chem Commun, 2009: 5999

[13] Arstad B, Kolboe S, Swang O. J Phys Chem A, 2005, 109: 8914

[14] Li J Z, Wei Y X, Chen J R, Tian P, Su X, Xu S T, Qi Y, Wang Q Y, Zhou Y, He Y L, Liu Z M. J Am Chem Soc, 2012, 134: 836

[15] Lesthaeghe D, De Sterck B, Van Speybroeck V, Marin G B, Waroquier M. Angew Chem Int Ed, 2007, 46: 1311

[16] Olsbye U, Svelle S, Björgen M, Beato P, Janssens T V W, Joensen F, 


\title{
Graphical Abstract
}

Chin. J. Catal., 2015, 36: 1017-1022 doi: 10.1016/S1872-2067(15)60842-7

Theoretical study on the geminal methylation of methylbenzene by halomethane over SAPO-34 molecular sieve

Lingtao Kong, Benxian Shen *

East China University of Science \& Technology
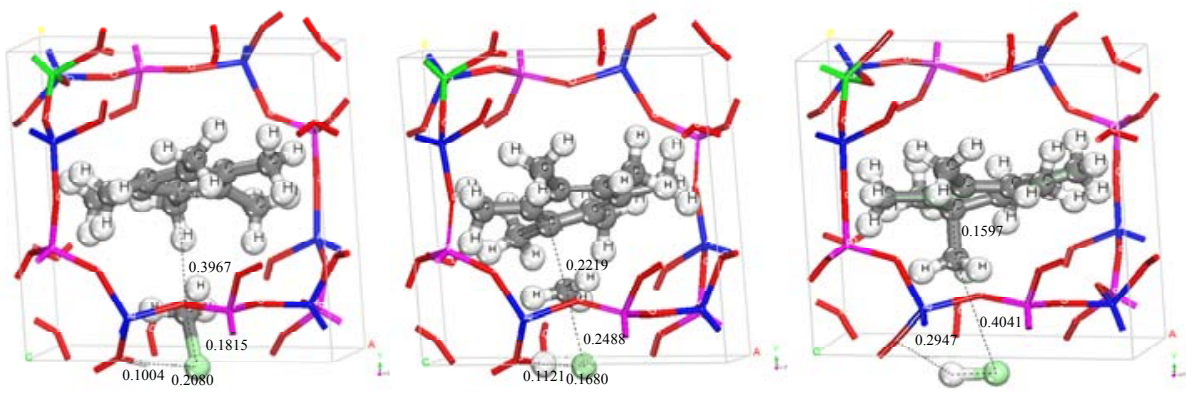

The geminal methylation of different methylbenzenes has been investigated within the framework of a HSAPO-34 catalyst using periodic density functional theory calculations. Hexamethylbenzene showed the lowest energy barriers for its geminal methylation reactions with $\mathrm{CH}_{3} \mathrm{Cl}$ and $\mathrm{CH}_{3} \mathrm{Br}$.

Bordiga S, Lillerud K P. Angew Chem Int Ed, 2012, 51: 5810

[17] Blaszkowski S R, van Santen R A. J Am Chem Soc, 1996, 118: 5152

[18] Wang C M, Wang Y D, Xie Z K, Liu Z P. J Phys Chem C, 2009, 113: 4584

[19] Wang C M, Wang Y D, Liu H X, Xie Z K, Liu Z P. J Catal, 2010, 271: 386

[20] Lo C, Trout B L.J Catal, 2004, 227: 77

[21] Bleken F, Svelle S, Lillerud K P, Olsbye U, Arstad B, Swang O.J Phys Chem A, 2010, 114: 7391

[22] Arstad B, Kolboe S, Swang 0. J Phys Chem B, 2002, 106: 12722
[23] Lesthaeghe D, Van Speybroeck V, Waroquier M. Phys Chem Chem Phys, 2009, 11: 5222

[24] Björgen M, Joensen F, Lillerud K P, Olsbye U, Svelle S. Catal Today, 2009, 142: 90

[25] Hereijgers B P C, Bleken F, Nilsen M H, Svelle S, Lillerud K P, Björgen M, Weckhuysen B M, Olsbye U.J Catal, 2009, 264: 77

[26] Olsbye U, Björgen M, Svelle S, Lillerud K P, Kolboe S. Catal Today, 2005, 106: 108

[27] Björgen M, Svelle S, Joensen F, Nerlov J, Kolboe S, Bonino F, Palumbo L, Bordiga S, Olsbye U. J Catal, 2007, 249: 195

\section{SAPO-34分子耖中多甲基苯分子与卤代甲烷偕甲基化反应的密度泛函理论研究}

\author{
孔令涛, 沈本贤 ${ }^{*}$ \\ 华东理工大学化学工程联合国家重点实验室, 上海200237
}

摘要: 利用周期性密度泛函理论研究了SAPO-34分子篮催化转化卤代甲烷制取低碳烯烃反应的碳池主要成分多甲基苯分子的偕 甲基化反应. 氯甲烷和溴甲烷分子在SAPO-34分子篮内的吸附能分别是 -18 和 $-22 \mathrm{~kJ} / \mathrm{mol}$, 由于氯和溴原子相似的电负性, 氯甲烷 和溴甲烷分子的吸附能并未被精确区分. 以氯甲烷和溴甲烷为甲基化试剂, 得到了几种多甲基苯分子的偕甲基化反应能及能垒, 结果表明, 六甲基苯分子(HMB)的偕甲基化反应为放热反应, 而其余甲基苯分子的偕甲基化反应为吸热反应. 对于上述两种甲基 化试剂, 体积最大的HMB均表现出最低的偕甲基化反应能垒, 这可能是由于分子篮骨架与多甲基苯分子之间的静电相互作用增 强了HMB的反应活性所致.

关键词: 偕甲基化反应; 氯甲烷; 溴甲烷; SAPO-34分子笁; 周期性密度泛函理论

收稿日期: 2015-01-22. 接受日期: 2015-03-20. 出版日期: 2015-07-20.

*通讯联系人. 电话: (021)64252916; 传真: (021)64252851; 电子信箱: sbx@ecust.edu.cn

本文的英文电子版由Elsevier出版社在ScienceDirect上出版(http://www.sciencedirect.com/science/journal/18722067). 